\title{
Peningkatan Pengetahuan dan Sikap Lansia terhadap Pencegahan Covid-19 melalui Aktivitas Fisik dan Hypnoterapi
}

\author{
DOI: https://doi.org/10.32509/abdimoestopo.v5i1.1748
}

\section{Mamay Maulana ${ }^{1}$, Rizki Siti Nurfitria ${ }^{2 *}$, Meti Sulastri ${ }^{3}$, Neneng Elviana ${ }^{4}$, Ratna Dian Kurniawati ${ }^{5}$}

\author{
${ }^{1,2}$ Fakultas Farmasi Universitas Bhakti Kencana pusat \\ Jl. Soekarno Hatta 754 Cibiru, Bandung 40617 \\ ${ }^{3}$ Fakultas Ilmu Kesehatan Universitas Bhakti Kencana cabang Tasikmalaya \\ Jl. R.E. Martadinata No.142 Cipedes, Tasikmalaya 46133 \\ ${ }^{4}$ Fakultas Keperawatan Universitas Bhakti Kencana cabang Jakarta \\ Jl. Raya Pondok Ranggon No.90, Cipayung, Jakarta Timur 13860 \\ ${ }^{5}$ Fakultas Ilmu Kesehatan Universitas Bhakti Kencana pusat \\ Jl. Soekarno Hatta 754 Cibiru, Bandung 40617
}

*Email korespondensi: rizki.sitinurfitria@bku.ac.id

\begin{abstract}
The elderly are a group of people who are more vulnerable to contracting Covid-19. Prevention of its transmission in the elderly group must be carried out optimally, because the elderly are at risk of experiencing more severe symptoms if infected with Covid-19. An effort to prevent the transmission of Covid-19 in the elderly is by taking preventive and promotive health measures. The purpose of this community service is to increase the knowledge and attitudes of the elderly towards the Covid-19 prevention protocol, especially physical activity and hypnotherapy. This activity uses a lecture method (counseling) which is carried out in hybrid way, namely a combination of offline and online activities through the Zoom application, as well as social service activities in the form of free health checks, breathing exercises and hypnotherapy workshops by presenting a hypnosis expert. Preand post-test questionnaires regarding physical activity and feedback questionnaires were administered to elderly groups to evaluate the success of the program. The results of the health examination showed that more than half of the elderly participants had clinical chemistry parameters of blood sugar and cholesterol above normal values indicating that most of the elderly had health conditions that needed special attention. Counseling which is the core of the program in general has resulted in increased knowledge and attitudes of the elderly towards health protocols and physical activity during the pandemic. Through this activity, it is hoped that elderly partners can improve health care efforts to prevent the transmission of Covid-19 and increase confidence in overcoming physical and psychological disorders due to the pandemic.
\end{abstract}

Keywords: Covid-19, elderly, hypnotherapy, physical activity, prevention.

\begin{abstract}
Abstrak - Lansia merupakan kelompok masyarakat yang lebih rentan tertular Covid-19. Pencegahan penularan virus ini pada kelompok lansia harus dilakukan secara maksimal, karena lansia beresiko mengalami gejala yang lebih berat jika terinfeksi Covid-19. Salah satu upaya untuk pencegahan penularan Covid-19 pada lansia yaitu dengan langkah promotif dan preventif kesehatan. Tujuan dari pengabdian masyarakat ini yaitu untuk meningkatkan pengetahuan dan sikap lansia terhadap protocol pencegahan Covid-19 khususnya aktivitas fisik dan hypnoterapi. Kegiatan ini dengan metode ceramah (penyuluhan) yang dilakukan secara hybrid yaitu kombinasi antara kegiatan luring dan daring melalui aplikasi Zoom, serta kegiatan bakti social berupa pemeriksaan kesehatan gratis, latihan nafas dan workshop hipnoterapi dengan menghadirkan seorang pakar hypnosis. Kuesioner pre- dan post-test mengenai aktivitas fisik dan kuesioner umpan balik diberikan kepada mitra untuk mengevaluasi keberhasilan program. Hasil pemeriksaan kesehatan menunjukkan bahwa lebih dari separuh peserta
\end{abstract}


lansia memiliki parameter kimia klinik gula darah dan kolesterol di atas angka normal menunjukkan bahwa sebagian besar mitra lansia memiliki kondisi kesehatan yang perlu mendapatkan perhatian khusus. Penyuluhan yang merupakan inti program secara umum telah menghasilkan luaran peningkatan pengetahuan dan sikap lansia terhadap protocol kesehatan dan aktivitas fisik selama pandemi. Melalui kegiatan ini diharapkan mitra lansia dapat meningkatkan upaya pemeliharaan kesehatan guna mencegah penularan Covid-19 serta meningkatkan kepercayaan diri dalam mengatasi gangguan fisik dan psikis akibat pandemi.

Kata Kunci: aktifitas fisik, Covid-19, hipnoterapi, lansia, preventif

\section{PENDAHULUAN}

Pandemi Covid-19 berdampak krisis pada berbagai sektor terutama yaitu pada sektor kesehatan yang berdampak menurunnya segala kondisi dan meningkatnya permasalahan pada masyarakat. Pemerintah tengah fokus dalam upaya penanggulangan wabah Covid-19 ini, seperti meningkatkan pelayanan kesehatan dengan memfasilitasi vaksin untuk masyarakat diantaranya lansia.

Merujuk pada data WHO, akibat dari wabah ini angka kematian paling tinggi terjadi pada penderita Covid-19 yang berusia 80 tahun ke atas dengan porsi mencapai lebih dari $22 \%$. Di Indonesia, proporsi angka kematian akibat Covid-19 tertinggi ada pada kelompok lansia sebesar 44\% (>60 tahun), kelompok umur 46-59 tahun sebesar 40\% dan 31-45 tahun sebesar 11,6\%. Lansia menurut Badan Kesehatan Dunia WHO, Kementerian Sosial merujuk pada UU no. 13 tahun 1998 tentang Kesejahteraan Lanjut Usia pada bab I pada Ketentuan Umum pasal 1 ayat 2 dan Kementerian Kesehatan tahun 2013 adalah seseorang yang telah mencapai usia 60 tahun ke atas.

Hasil studi pendahuluan melalui observasi langsung dan wawancara yaitu terdapatnya kelompok lansia di wilayah Kelurahan Pondok Ranggon Kecamatan Cipayung Jakarta Timur dengan jumlah yang cukup banyak. Covid-19 merupakan penyakit menular yang menyerang sistem pernafasan pada manusia sehingga dapat menimbulkan tingkat kematian yang selalu meningkat. Virus ini sangat mudah menempel pada lansia yang dimana tubuh mengalami penurunan pada sistem kekebalan tubuh sehingga kemungkinan terkena virus sangatlah mudah (Maulana \& Bawono, 2021). Kelompok lansia sebagian besar memiliki komorbid dan sedang dalam pengobatan jangka panjang. Oleh karena itu, lansia merupakan kelompok masyarakat yang lebih rentan tertular Covid-19 (Pradana et al., 2020). Pneumonia atau paru-paru basah, memiliki \% angka kejadian tertinggi akibat yang ditimbulkan Covid -19. Hampir semua pasien positif Covid-19 yang meninggal di seluruh daerah juga mengidap penyakit kronis atau penyakit penyerta tersebut.

Selain itu, mereka mengatakan bahwa pandemi ini menjadikan mereka lebih mudah stress. Hasil penelitian sebelumnya menunjukkan bahwa lansia memiliki tingkat kekhawatiran sangat tinggi pada masa pandemi Covid-19 (Al Mubarroh et al., 2021). Sejalan dengan hasil penelitian yang lain, dikatakan.bahwa lansia pada masa pandemi Covid-19 sebagian besar mengalami depresi ringan (Hartutik \& Nurrohmah, 2021). Kebijakan pembatasan sosial nyatanya telah menimbulkan berbagai permasalahan baru pada lansia. Instruksi bagi masyarakat termasuk lansia untuk tetap di rumah saja menyebabkan mereka tidak dapat bepergian ke tempat kerabat seperti keluarga, teman, fasilitas kesehatan, dan tempat ibadah sehingga mereka mengalami rasa kesepian, merasa terpencil, dan terisolasi. Selain itu, isolasi sosial pada lansia dapat berkembang menjadi masalah kesehatan yang serius karena risikonya yang tinggi terhadap gangguan kardiovaskuler, autoimun, neurokognitif, dan kesehatan mental. Pembatasan sosial dapat menimbulkan gejala kecemasan dan depresi pada populasi orang dewasa yang lebih tua, yaitu usia 57-85 tahun (Muliani et al., 2021). 
Berdasarkan paparan di atas, jelas bahwa pencegahan Covid pada kelompok lansia harus dilakukan secara maksimal, karena kelompok ini beresiko mengalami gejala yang lebih berat jika terinfeksi Covid-19. Oleh karena itu, rumusan masalah yang ditemukan dalam kegiatan pengabdian masyarakat ini yaitu kurangnya pengetahuan dan sikap lansia terhadap protocol pencegahan Covid-19 khususnya dalam mengatasi keluhan fisik dan psikis selama pandemi.

Mengacu dari hal tersebut maka sangat penting untuk selalu memotivasi lansia untuk tetap melakukan aktivitas fisik untuk meningkatkan kesehatan, imunitas tubuh, mempertahankan kebugaran, serta mengurangi depresi dan rasa kekhawatiran pada masa pandemi Covid-19 (Al Mubarroh et al., 2021). Salah satu upaya untuk pencegahan penularan Covid-19 pada lansia ialah dengan langkah promotif dan preventif, antara lain dengan pemberian edukasi pada lansia (Melia et al., 2020; Sari \& Daryanto, 2021). Tujuan kegiatan pengabdian masyarakat ini yaitu untuk meningkatkan pengetahuan dan sikap lansia tentang protokol pencegahan Covid-19 khususnya aktivitas fisik dan hypnoterapi.

Aktifitas fisik merupakan rangkaian kegiatan yang membutuhkan energi untuk melakukannya, biasanya berupa kegiatan yang dilakukan paling sedikit 10 menit tanpa henti. Aktivitas fisik dibagi atas tiga tingkatan yakni aktivitas fisik ringan, sedang dan berat. Aktivitas fisik ringan adalah segala sesuatu yang berhubungan dengan menggerakkan tubuh, diantaranya yang biasa dilakukan lansia seperti membaca dan menonton televisi. Aktivitas fisik sedang adalah pergerakan tubuh yang menyebabkan pengeluaran tenaga cukup besar, dengan kata lain bergerak yang menyebabkan nafas sedikit lebih cepat dari biasanya. Contoh aktivitas yang biasa dilakukan lansia seperti membuat kerajinan tangan, membaca, dan berkebun. Aktivitas fisik berat adalah pergerakan tubuh yang menyebabkan pengeluaran tenaga cukup banyak (pembakaran kalori) sehingga nafas jauh lebih cepat dari biasanya. Contoh aktivitas yang biasa dilakukan lansia yaitu mengerjakan pekerjaan rumah tangga dan mengasuh cucu (Al Mubarroh et al., 2021).

Aktivitas fisik yang terencana dan terstruktur melibatkan gerakan tubuh yang dilakukan secara berulang-ulang dan bertujuan untuk kesegaran jasmani disebut dengan olahraga. Seperti halnya aktivitas fisik, olahraga juga terbagi menjadi beberapa kategori, yaitu aktivitas olahraga dengan kategori ringan, diantaranya yang sering dilakukan lansia adalah jalan kaki dan memancing. Aktivitas olahraga dengan kategori sedang yang sering dilakukan lansia adalah bersepeda dan tenis meja. Sedangkan aktivitas olahraga dengan kategori berat yang sering dilakukan lansia seperti jogging dan angkat beban (latihan otot). Hasil penelitian sebelumnya menunjukkan bahwa ada pengaruh latihan fisik terhadap kebugaran lansia dalam masa pandemi Covid-19 (Anuar et al., 2021).

Sedangkan hipnosis adalah keadaan alami dari relaksasi total tubuh dimana kondisi kesadaraan pikiran meningkat lebih tinggi daripada biasanya. Ketika memasuki keadaan hypnosis, kesadaran terhadap apa yang terjadi di sekitar akan berkurang bila dibandingkan kesadaran terhadap perasaan-perasaan di dalam diri manusia. Oleh karena itu, manusia akan memfokuskan perhatian kepada sugesti yang ditanamkan dalam diri sebagai upaya mengatasi suatu masalah. Hipnoterapi adalah terapi yang menggunakan hypnosis untuk memfasilitasi perubahan. Sugesti yang telah disetujui sebelumnya ditanamkan ke dalam alam bawah sadar sementara manusia berada dalam keadaan relaks terhipnosis. Hipnoterapi adalah terapi pikiran yang dilakukan dalam kondisi hypnosis, sedangkan hypnosis itu sendiri adalah kondisi relaksasi pikiran dan tubuh, dalam kondisi ini pikiran lebih mudah dan terbuka terhadap perubahan. Hipnosis bisa dimanfaatkan untuk melakukan berbagai kebutuhan diantaranya untuk mengatasi masalah psikologis seperti trauma, phobia, ketakutan, kecemasan dan lainlain (Fitriko, 2020). 


\section{METODE PELAKSANAAN}

Sesuai dengan permasalahan mitra yang sudah di jelaskan pada bab di atas maka solusi yang dapat diberikan untuk menangani permasalahan lansia sesuai dengan kompetensi yang dimiliki oleh tim pengusul yaitu dengan melakukan kegiatan promotive dan preventif kesehatan. Tim pengusul mempunyai kepakaran yang berbeda-beda yang dapat berkontribusi dalam upaya pemecahan permasalahan mitra. Untuk menjaga kesehatan lingkungan seperti penerapan protokol kesehatan dalam kehidupan sehari-hari, dengan adanya background kesehatan masyarakat dan farmasi sosial dapat membantu lansia lebih disiplin mematuhi protocol kesehatan dan memantau kesehatannya secara mandiri. Untuk meningkatkan pengetahuan dan sikap guna mengatasi keluhan fisik dan psikis lansia maka dengan adanya background keperawatan dan khususnya pakar hypnoterapi diharapkan dapat membantu lansia mengatasi masalah yang terkait.

Kegiatan inti dari pengabdian masyarakat dilakukan dengan metode ceramah berupa penyuluhan kepada mitra lansia sebanyak 31 peserta yang dilakukan secara hybrid yaitu kombinasi antara kegiatan luring dan daring melalui aplikasi Zoom yang bertempat di Aula Universitas Bhakti Kencana Jakarta Timur. Kegiatan bakti social berupa pengecekan parameter kimia klinik darah dan tekanan darah secara gratis, latihan nafas untuk lansia dan juga workshop hipnoterapi dengan menghadirkan seorang perawat senior yang juga merupakan pakar hypnosis.

Tahapan yang dilaksanakan dalam pelaksanaan program yaitu: 1) Identifikasi masalah yang dihadapi oleh mitra lansia di Kelurahan Pondok Ranggon Kecamatan Cipayung Jakarta Timur, 2) Analisis kebutuhan mitra lansia dalam upaya penanggulangan masalah, 3) Pengurusan surat ijin dan koordinasi ke pihak terkait (kelurahan, puskesmas, RT, RW, Kader) terkait program yang akan dijalankan, 4) Kegiatan inti berupa penyuluhan dan bakti social dalam bentuk pengecekan parameter kimia klinik darah dan tekanan darah, latihan nafas untuk lansia dan hipnoterapi dengan menghadirkan seorang pakar.

Materi penyuluhan diberikan dalam 2 (dua) sesi yaitu materi mengenai protocol kesehatan lansia di masa pandemi oleh seorang dokter Puskesmas dan materi self-hypnosis yang diberikan oleh seorang perawat yang juga merupakan pakar hypnoterapi. Materi edukasi yang diberikan dalam sesi pertama diantaranya mengenai resiko Covid-19 terhadap lansia, protocol kesehatan lansia di masyarakat, pencegahan penularan Covid-19 pada lansia secara umum yang mencakup menjaga pola makan, aktivitas fisik, manajemen stress, pemantauan kesehatan dan vaksinasi bagi lansia (Kemenkes RI, 2020). Penekanan khusus diberikan pada materi tindakan apa yang perlu dilakukan oleh lansia di masa pandemi jika mereka tinggal bersama pendamping, di panti wreda, atau tinggal sendiri berkaitan dengan banyaknya kondisi dementia yang dialami oleh lansia (Turana et al., 2021). Keterampilan kesehatan yang diberikan dalam penyuluhan diantaranya langkah cuci tangan yang benar, etika batuk atau bersin, cara memakai masker yang benar, cara mengukur tekanan darah dan pemeriksaan gula darah secara mandiri, dan mengenal tanda kegawat daruratan (Kemenkes RI, 2020; Kemensos RI, 2020).

Luaran Pembangunan dari kegiatan ini yaitu untuk meningkatkan kesadaran mitra lansia mengenai protokol kesehatan untuk mencegah Covid-19, meningkatkan status kesehatan lansia, dan menciptakan suasana kondusif agar terhindar dari stress. Penurunan fungsi fisik dan psikososial pada lansia dapat menjadi salah satu penghambat bagi lansia dalam menerapkan protokol Kesehatan (Kristamuliana et al., 2021; Turana et al., 2021).

Pengabdian masyarakat ini berhasil ketika keberlanjutan kegiatan dalam program tersebut bisa terlaksana meskipun kegiatan pengabdian masyarakat telah berakhir. Adapun cara untuk menjaga keberlanjutan program tersebut yaitu dengan menyediakan wadah untuk konsultasi kesehatan lansia dan memberikan kuesioner post-test mengenai protokol kesehatan 
lansia terutama aktivitas fisik. Keberhasilan kegiatan juga dievaluasi melalui kuesioner umpan balik atau feedback dari mitra guna memperbaiki kualitas kegiatan dan pencapaian program LPPM secara berkelanjutan.

\section{HASIL PENEMUAN DAN DISKUSI}

Pelaksanaan kegiatan pengabdian masyarakat dilakukan pada saat pandemi yaitu pada hari Kamis, 4 Oktober 2021. Tim mahasiswa memberikan kuesioner pre-test mengenai protocol kesehatan bagi lansia di masa pandemi dan aktivitas fisik sebelum dimulainya penyuluhan dengan pendampingan responden saat pengisian. Tim mahasiswa juga menjadi fasilitator selama kegiatan berlangsung termasuk saat senam ice breaking, sesi tanya jawab setelah penyampaian materi penyuluhan, dan workshop hypnoterapi. Hal ini bertujuan agar para lansia merasa terbantu dan lebih mudah memahami pesan kesehatan yang di sampaikan dalam protokol kesehatan Covid-19 (Jayanti \& Rahmawati, 2021). Pada saat mitra lansia datang ke lokasi kegiatan, dilakukan pemeriksaan kesehatan gratis yaitu tekanan darah dan kimia klinik glukosa darah sewaktu, kolesterol total dan asam urat. Gambaran status kesehatan mitra lansia dapat dilihat pada Tabel 1 di bawah ini.

Tabel 1. Hasil Pemeriksaan Parameter Kimia Klinik Mitra Lansia

\begin{tabular}{|c|c|c|c|c|c|c|c|c|c|c|c|}
\hline \multicolumn{4}{|c|}{ Tekanan darah } & \multirow{2}{*}{$\begin{array}{c}\text { Gula darah } \\
\text { sewaktu }\end{array}$} & \multirow{2}{*}{$F(\%)$} & \multirow{2}{*}{$\begin{array}{c}\text { Kolesterol } \\
\text { total }\end{array}$} & \multirow{2}{*}{$F(\%)$} & \multicolumn{4}{|c|}{ Asam urat } \\
\hline Sistol & $F(\%)$ & Diastol & $F(\%)$ & & & & & Pria & $F(\%)$ & Wanita & $F(\%)$ \\
\hline$<140 \mathrm{mmHg}$ & $17(54,8)$ & $<90 \mathrm{mmHg}$ & $28(90,3)$ & $<100 \mathrm{mg} / \mathrm{dl}$ & $8(25,8)$ & $<200 \mathrm{mg} / \mathrm{dl}$ & $12(38,7)$ & $<7 \mathrm{mg} / \mathrm{dl}$ & $2(6,5)$ & $<6 \mathrm{mg} / \mathrm{dl}$ & $17(54,8)$ \\
\hline$>140 \mathrm{mmHg}$ & $14(45,2)$ & $>90 \mathrm{mmHg}$ & $3(9,7)$ & $>100 \mathrm{mg} / \mathrm{dl}$ & $23(74,2)$ & $>200 \mathrm{mg} / \mathrm{dl}$ & $19(61,3)$ & $>7 \mathrm{mg} / \mathrm{dl}$ & $3(6,5)$ & $>6 \mathrm{mg} / \mathrm{dl}$ & $10(32,2)$ \\
\hline Total & $31(100)$ & & $31(100)$ & Total & $31(100)$ & Total & $31(100)$ & Total & $4(13)$ & & $27(87)$ \\
\hline
\end{tabular}

Dari data diatas dapat terlihat bahwa sebagian besar peserta lansia memiliki parameter kimia klinik darah di atas angka normal, yaitu pada pemeriksaan gula darah sewaktu dan kolesterol total. Selain itu, sebanyak 45,2\% mitra lansia memiliki tekanan darah sistol lebih besar dari $140 \mathrm{mmHg}$. Hal ini menunjukkan bahwa sebagian besar mitra lansia memiliki kondisi kesehatan yang perlu mendapatkan perhatian khusus. Kelompok masyarakat lansia sangat rentan untuk tertular infeksi jika memiliki komorbid atau mengidap penyakit kronis atau penyakit penyerta lain (Kristamuliana et al., 2021).

Materi penyuluhan diberikan dalam 2 (dua) sesi yaitu materi mengenai protocol kesehatan lansia di masa pandemi oleh seorang dokter Puskesmas dan materi self-hypnosis yang diberikan oleh seorang perawat yang juga merupakan pakar hypnoterapi. Berikut ini dokumentasi pelaksanaan kegiatan pengabdian masyarakat seperti terlihat pada Gambar 1.

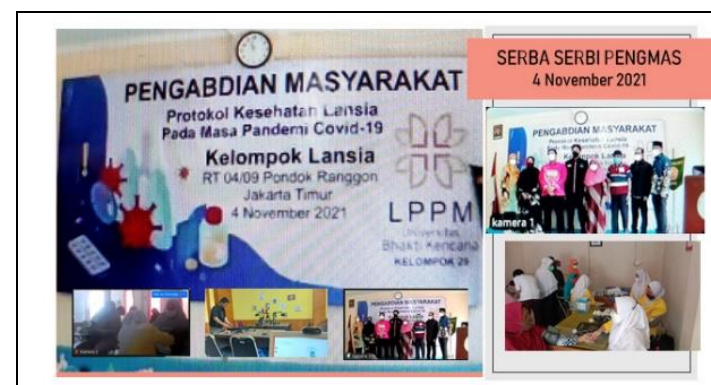

(a)

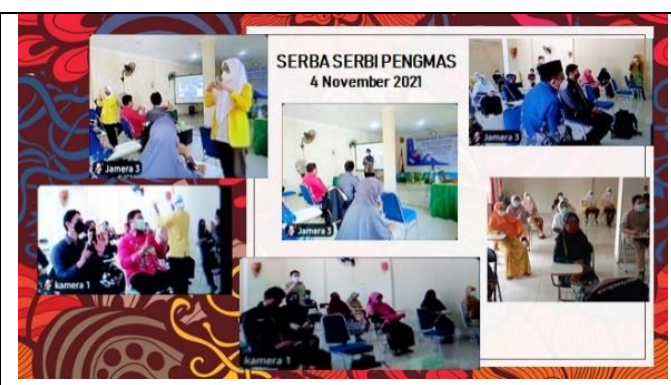

(b) 


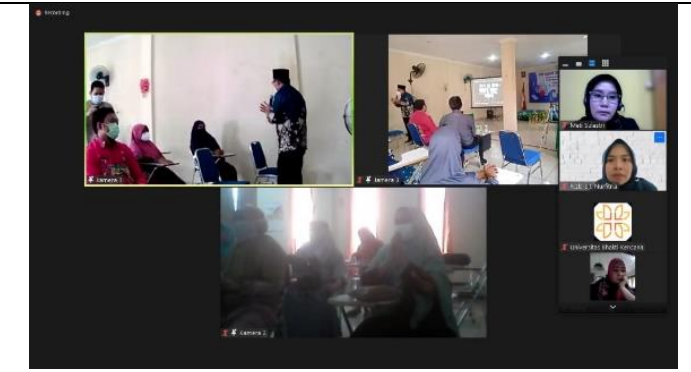

(c)

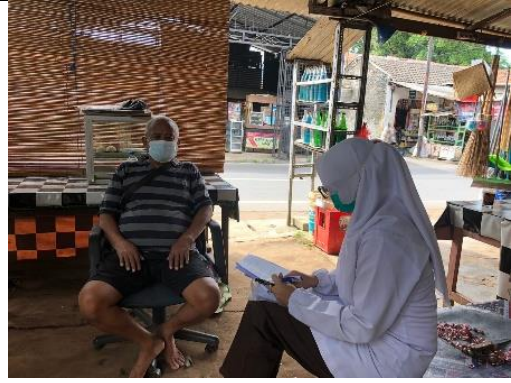

(d)

Gambar 1. Dokumentasi Pelaksanaan Kegiatan Pengabdian Masyarakat pada Mitra Lansia Kelurahan Pondok Ranggon, Jakarta Timur; (a) Suasana kegiatan pengabdian masyarakat di Aula Universitas Bhakti Kencana Jakarta, termasuk pemeriksaan kesehatan gratis dan foto bersama penyelenggara dan pemateri, (b) Suasana sesi penyuluhan dibantu dengan fasilitator mahasiswa, (c) Penyampaian materi self-hypnosis oleh pakar dan sesi tanya jawab oleh moderator Zoom, (d) kegiatan pemantauan dan evaluasi pasca kepada mitra lansia dibantu oleh mahasiswa. (Sumber: Dokumentasi Tim Pengusul)

Program ini memiliki capaian akhir bagi lansia untuk mengetahui upaya pemeliharaan kesehatan lansia di tengah pandemi dan meningkatkan pengetahuan serta sikap lansia untuk dapat mencegah gangguan fisik dan psikis selama pandemi secara percaya diri. Oleh karena itu, dilakukan pengisian kembali kuesioner post-test yang dilakukan satu minggu pasca penyuluhan, untuk mengukur skor pengetahuan dan sikap peserta lansia setelah penyuluhan. Setiap aspek pengetahuan dinilai dengan skor 1 (satu) untuk jawaban benar dan 0 (nol) untuk jawaban salah. Sedangkan aspek sikap dinilai dengan skala likert 1 (tidak setuju) hingga 4 (sangat setuju). Berikut distribusi frekuensi hasil pre- dan post-test yang didapatkan dari 22 responden (sebagian peserta hanya mengisi hanya salah satu pre-test atau post-test saja sehingga datanya tidak lengkap).

Tabel 2. Sebaran Tingkat Pengetahuan dan Sikap Responden terhadap Protokol Kesehatan Lansia dan Aktivitas Fisik di Masa Pandemi Covid-19 Sebelum dan Sesudah Penyuluhan

\begin{tabular}{lcccc}
\hline & \multicolumn{2}{c}{ Sebelum Penyuluhan } & \multicolumn{2}{c}{ Setelah Penyuluhan } \\
\cline { 2 - 5 } \multicolumn{1}{c}{ Variabel } & F & $\mathbf{\%}$ & F & \% \\
\hline Pengetahuan & & & & \\
Baik & 9 & 41 & 15 & $\mathbf{6 8}$ \\
Cukup & 13 & $\mathbf{5 9}$ & 7 & 32 \\
\hline Sikap & & & & \\
Mendukung & 14 & $\mathbf{6 4}$ & 19 & $\mathbf{8 6}$ \\
$\quad$ Tidak mendukung & 8 & 36 & 3 & 14 \\
\hline Total & 22 & 100 & 22 & 100 \\
\hline
\end{tabular}

Tabel 3. Rerata dan Perbedaan Rerata Skor Pengetahuan dan Sikap Responden terhadap Protokol Kesehatan Lansia dan Aktivitas Fisik di Masa Pandemi Covid-19 sebelum dan sesudah Penyuluhan

\begin{tabular}{lcc}
\hline \multicolumn{1}{c}{ Variabel } & Rerata & Perbedaan Rerata \\
\hline Pengetahuan & & \\
Sebelum Penyuluhan & 7,91 & \\
Setelah Penyuluhan & 8,32 & $\mathbf{0 , 4 1}$ \\
\hline Sikap & & \\
Sebelum Penyuluhan & 2,70 & \\
Setelah Penyuluhan & 3,00 & $\mathbf{0 , 3 0}$ \\
\hline
\end{tabular}


Dari kedua tabel di atas (Tabel 2 dan Tabel 3) dapat terlihat bahwa skor pengetahuan sebagian besar peserta baik sebelum penyuluhan tergolong kategori cukup (59\%) dan setelah penyuluhan tergolong kategori baik $(68 \%)$ dengan perbedaan rerata yang positif. Hal ini menunjukkan bahwa terdapat peningkatan pengetahuan mitra lansia terhadap protocol kesehatan selama pandemik dan aktivitas fisik. Skor sikap sebagian besar peserta baik sebelum dan setelah penyuluhan tergolong kategori mendukung (64\% dan 86\%) dengan perbedaan rerata yang positif. Hal ini menunjukkan bahwa terdapat peningkatan sikap mitra lansia terhadap protocol kesehatan selama pandemic dan aktivitas fisik.

Covid-19 merupakan penyakit menular yang menyerang sistem pernafasan pada manusia sehingga dapat menimbulkan tingkat keparahan bahkan kematian pada individu dengan system kekebalan tubuh yang berbeda-beda. Virus ini sangat mudah menempel pada lansia yang dimana tubuh mengalami penurunan pada sistem kekebalan tubuh sehingga kemungkinan terkena virus sangatlah mudah. Salah cara untuk melakukan pencegahan terhadap virus Covid19 adalah dengan melakukan aktivitas fisik yang terukur. Dengan melakukan aktivitas olahraga yang teratur dalam artian melakukan aktivitas dengan porsi yang sesuai pada lansia akan menguntungkan karena secara tidak sadar aktivitas fisik yang teratur akan menyebabkan peningkatan sistem imun pada lansia sehingga tidak mudah terkena virus Covid-19. Aktivitas olahraga yang sangat dianjurkan bagi lansia adalah olahraga anaerobik seperti jalan kaki, bersepeda dan senam lansia dikarenakan lebih mudah dan efektif untuk melakukan gerakan olahraga tersebut (Maulana \& Bawono, 2021). Hal ini juga sejalan dengan hasil penelitian lainnya bahwa senam aerobik dengan intensitas ringan adalah mudah, murah, dan dapat meriah serta bermanfaat karena dilakukan di dalam rumah dan akan menyebabkan denyut jantung lansia masuk ke dalam training zone sehingga akan memenuhi tuntutan dan persyaratan pelatihan (Syahruddin, 2020). Sedangkan pada pustaka yang lain disebutkan bahwa aktivitas fisik yang harus dilakukan lansia meliputi latihan aerobic, kekuatan, dan keseimbangan dengan intensitas sedang yang dapat dilakukan seperti berjalan kaki, latihan peregangan yang dilakukan 10 menit/hari, bersepeda, atau olahraga lainnya yang disesuaikan dengan kondisi fisik dan lingkungan lansia (Al Mubarroh et al., 2021). Aktivitas olahraga dapat mampu meningkatkan sistem imunitas, kesehatan mental, kesehatan metabolik, kekuatan otot dan fungsi kardiovaskular sehingga meningkatkan sistem kekebalan secara keseluruhan pada tubuh lansia (Maulana \& Bawono, 2021).

Pengetahuan lansia akan aktivitas fisik dimasa pandemi dapat diperoleh dari pengalaman kegiatan-kegiatan yang diikuti lansia, sebagai contoh ketika aktif dalam Posbindu Lansia, mengikuti penyuluhan, dan membaca dari media cetak maupun elektronik. Salah satu upaya untuk terus meningkatkan pengetahuan, sikap dan perilaku lansia sebagai salah satu kelompok berisiko adalah dengan terus memberikan pengetahuan mengenai faktor-faktor yang dapat meningkatkan imunitas di masa pandemi salah satunya dengan melakukan aktivitas fisik. Aktifitas fisik pada dasarnya sudah menjadi perhatian pemerintah dalam program Germas yang target sasarannya bukan hanya lansia akan tetapi semua golongan usia. Melalui penyuluhan yan berkelanjutan diharapkan akan menambah dan merubah pengatahuan dan sikap masyarakat terutama Lansia untuk terus menerapkan gaya hidup sehat (Wulan et al., 2021).

Sikap yang terbentuk pada lansia merupakan respon dengan banyak stimulus termasuk pendukung dan kendala melakukan aktivitas fisik di masa pandemi. Kegiatan yang terbiasa dilakukan tanpa batasan pada masa pandemi menjadi terbatas di segala aspek yang secara simultan membuat respon sebagai hambatan tersendiri bagi lansia. Adanya informasi dari petugas kesehatan pada lansia akan menjadi stimulus respon lansia dalam menyikapi aktivitas fisik yang tetap harus dilaksanakan di masa pandemi. Adanya kemudahan dan informasi tentang jenis dan cara aktifitas fisik yang dapat dengan mudah dilakukan mandiri di rumah menjadi informasi yang akan merubah sikap lansia tentang pentingnya aktifitas fisik itu sendiri. Lansia akan merasa percaya diri melakukan aktifitas fisik secara mandiri. Tetap aktif secara 
fisik di masa pandemi COVID-19 merupakan hal yang sangat sangat penting karena dapat meningkatkan kesehatan, mempertahankan kebugaran, meningkatkan imunitas, mengurangi depresi dan rasa kekhawatiran, serta mampu mencegah berbagai faktor risiko penyakit tidak menular (Al Mubarroh et al., 2021).

Keberhasilan kegiatan juga dievaluasi guna memperbaiki kualitas kegiatan dan pencapaian program LPPM secara berkelanjutan. Hal ini dilakukan melalui kuesioner umpan balik atau feedback kepada mitra. Hasil survey menunjukkan bahwa kepuasan mitra lansia terhadap program yang diberikan menghasilkan rerata nilai 3,2 dari skor maksimal 4 atau sebesar 79\%. Rerata nilai item terbesar sebesar 3,3 didapatkan dari poin 'pengusul kegiatan telah melaksanakan sosialisasi kepada mitra atas program yang akan diterapkan kepada lansia'.

Kegiatan ini juga telah menghasilkan luaran lain berupa publikasi media massa yang dapat diakses melalui https://jabar.tribunnews.com/2021/11/27/peningkatan-pengetahuan-aktifitasfisik-dan-protokol-kesehatan-covid-19-serta-upaya-self-healing dan video Youtube yang dapat diakses melalui https://www.youtube.com/watch?v=z3-QOCoFpRU seperti yang tercantum pada gambar 2 berikut.

\section{SIMPULAN}

Kegiatan pengabdian kepada masyarakat berupa edukasi dan bakti social yang dilaksanakan secara luring dan daring yang bertemakan promosi kesehatan lansia di masa pandemi ini telah berjalan dengan baik dan lancar. Penyuluhan yang merupakan inti program secara umum telah menghasilkan luaran peningkatan pengetahuan dan sikap lansia terhadap protocol kesehatan guna mencegah Covid-19 khususnya aktivitas fisik dan hypnoterapi selama pandemi. Melalui kegiatan ini diharapkan mitra lansia dapat meningkatkan upaya pemeliharaan kesehatan guna mencegah penularan Covid-19 serta meningkatkan kepercayaan diri dalam mengatasi gangguan fisik dan psikis akibat pandemi.

\section{Ucapan Terima Kasih}

Pengusul mengucapkan terima kasih kepada Lembaga Penelitian dan Pengabdian Masyarakat Universitas Bhakti Kencana selaku pemberi dana hibah pengabdian masyarakat, Puskesmas Pondok Ranggon Jakarta Timur dan para mahasiswa Universitas Bhakti Kencana cabang Jakarta yang telah membantu terselenggaranya kegiatan Pengabdian Masyarakat Dosen tahun 2021.

\section{Daftar Pustaka}

Al Mubarroh, N. R., Susanto, I. H., \& Mustar, Y. S. (2021). Aktivitas fisik dan aspek kekhawatiran lansia pada masa pandemi Covid-19. Altius: Jurnal Ilmu Olahraga Dan Kesehatan, 10(1), 97-111. https://doi.org/10.36706/altius.v10i1.14140

Anuar, R., Imani, D. R., \& Norlinta, S. N. O. (2021). Pengaruh Latihan Fisik Terhadap Kebugaran Lansia Dalam Masa Pandemi Covid-19: Narrative Review. FISIO MU: Physiotherapy Evidences, 2(2), 95-106. https://doi.org/10.23917/fisiomu.v2i2.13978

Fitriko, A. (2020). Asuhan Keperawatan Komunitas Dengan Penerapan Hipnoterapi Untuk Penurunan Kecemasan Pada Kader Sebelum Dilakukan Swab Test Covid-19 Dikelurahan Sapiran Kotabukittinggi Tahun 2020 [STIKes Perintis Indonesia]. http://repo.stikesperintis.ac.id/1168/1/3 AKHYAR FITRIKO.pdf

Hartutik, S., \& Nurrohmah, A. (2021). Gambaran Tingkat Depresi Pada Lansia Di Masa Pandemic Covid-19. Jurnal Ilmu Keperawatan Komunitas, 4(1), 6-18. https://doi.org/10.32584/jikk.v4i1.911

Jayanti, I., \& Rahmawati, W. (2021). Tingkat Pemahaman Lansia Mengenai Pesan Protokol Kesehatan Covid-19. The 13th University Research Colloqium, Sekolah Tinggi Ilmu 
Kesehatan Muhammadiyah Klaten, 1047-1053.

Kemenkes RI. (2020). Panduan Pelayanan Kesehatan Lanjut Usia Pada Era Pandemi Covid19. In Kementrian Kesehatan RI (Issue April).

Kemensos RI, K. R. (2020). Panduan Pencegahan Covid 19 Bagi Pendamping LKS-LU Program Rehabilitasi Sosial Lanjut Usia. In Direktorat Rehabilitasi Sosial Lanjut Usia Kementerian Sosial: Vol. (Issue).

Kristamuliana, K., Renteng, S., \& Datu, R. J. (2021). Pengalaman Lansia Menerapkan Protokol Kesehatan di Masa Pandemi Covid-19: Studi Kualitatif di BPLU Senja Cerah Manado. Media Publikasi Promosi Kesehatan Indonesia, 4(3), 406-412. http://https//www.era.lib.ed.ac.uk , handle , Andrea Wallace_Repository Fringe\%0Afile:///C:/Users/Kioko/Documents/Citavi 5/Projects/PhD Project may 2018/Citavi Attachments/Wallace - Open Access \& Open GLAM.pdf Y3 - 10 March 2018 M4 - Citavi

Maulana, G. W., \& Bawono, M. N. (2021). Peningkatan Imunitas Tubuh Lansia Melalui Olahraga Pada Saat Pandemi Covid-19. Jurnal Kesehatan Olahraga, 9(3), 221-220. https://ejournal.unesa.ac.id/index.php/jurnal-kesehatan-olahraga/article/view/41146

Melia, S., Triana, H., \& Prasetyo, Y. A. (2020). Edukasi kesehatan lansia dan adaptasi kebiasaan baru melalui media live streaming Youtube. Seminar Nasional Semnas LPPM Universitas Muhammadiyah Purwokerto, 150-153.

Muliani, R., Jayanti, T. N., Dirgahayu, I., \& Safarudin, I. (2021). Psychosocial Support in Increasing Covid-19 and Mental Health in Elderly. JCES (Journal of Character Education Society), $4(1)$, http://journal.ummat.ac.id/index.php/JCES/article/view/3445/pdf

$135-147$.

Pradana, A. A., Casman, \& Nur'aini. (2020). Pengaruh Kebijakan Social Distancing pada Wabah COVID-19 terhadap Kelompok Rentan di Indonesia. Jurnal Kebijakan Kesehatan Indonesia : JKKI, 9(2), 61-67. https://jurnal.ugm.ac.id/jkki/article/view/55575

Sari, M. T., \& Daryanto, D. (2021). Edukasi Lansia Sehat Dan Bahagia (Smart) Pada Masa Pandemi Covid-19 Di Puskesmas Tempino Muaro Jambi. LOGISTA - Jurnal Ilmiah Pengabdian Kepada Masyarakat, 5(1), 35. https://doi.org/10.25077/logista.5.1.3541.2021

Syahruddin, S. (2020). Kebugaran Jasmani Bagi Lansia Saat Pandemi Covid-19. JUARA : Jurnal Olahraga, 5(2), 232-239. https://doi.org/10.33222/juara.v5i2.943

Turana, Y., Fitri, F. I., Theresia, I., \& Sani, T. P. (2021). Panduan Praktis Pendampingan Lansia dengan Demensia saat Pandemi COVID-19. In Alzheimer Indonesia - Stride. https://alzi.or.id/

Wulan, S., Gurusinga, R., Ginting Munthe, N. B., Lubis, B., \& Markus, I. (2021). Penyuluhan Protokol Kesehatan Dengan Media Video Dan Leaflet Terhadap Pengetahuan Dan Sikap Lansia Tentang Pencegahan Covid-19. Jurnal Pengmas Kestra (Jpk), 1(1), 34-37. https://doi.org/10.35451/jpk.v1i1.707 